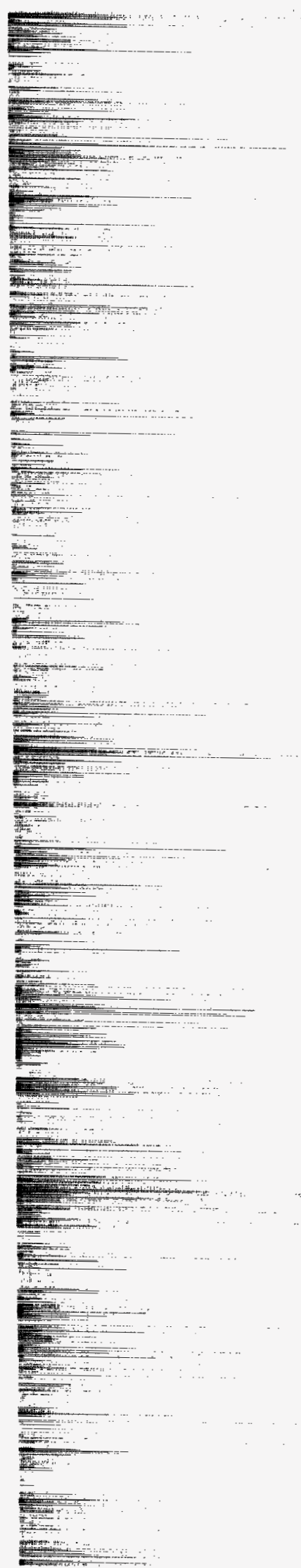

Survey of Plutonium and Uranium Atom

Ratios and Activity Levels in

Mortandad Canyon

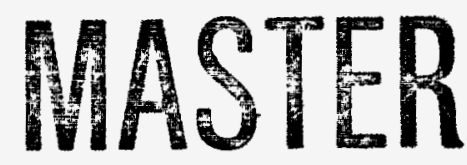

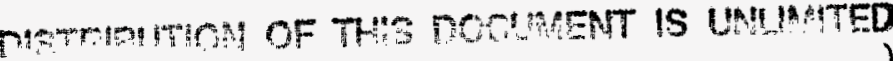


Edited by Hector Hinojosa, Group CIC-1

An Affirmative Action/Equal Opportunity Employer

This report was prepared as an account of work sponsored by an agency of the United States Government. Neither The Regents of the University of California, the United States Government nor any agency thereof, nor any of their employees, makes any warranty, express or implied, or assumes any legal liability or responsibility for the accuracy, completeness, or usefulness of any information, apparatus, product, or process disclosed, or represents that its use would not infringe privately owned rights. Reference herein to any specific commercial product, process, or seroice by trade name, trademark, manufacturer, or otherwise, does not necessarily constitute or imply its endorsement, recommendation, or favoring by The Regents of the University of California, the United States Government, or any agency thereof. The views and opinions of authors expressed herein do not necessarily state or reflect those of The Regents of the University of California, the United States Government, or any agency thereof. Los Alamos National Laboratory strongly supports academic freedom and a researcher's right to publish; as an institution, however, the Laboratory does not endorse the viewpoint of a publication or guarantee its technical correctness. 
UC-903 and UC-940

Issued: October 1997

Survey of Plutonium and Uranium Atom

Ratios and Activity Levels in

\section{Mortandad Canyon}
B. M. Gallaher
D. W. Efurd ${ }^{2}$
D. J. Rokop ${ }^{3}$
T. M. Benjamin ${ }^{2}$
A. K. Stoker

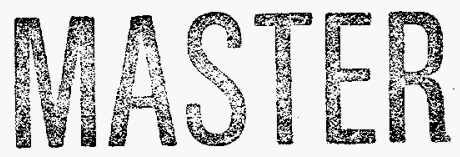

${ }^{1}$ Water Quality and Hydrology Group, Los Alamos National Laboratory

${ }^{2}$ Radiochemistry Group, Los Alamos National Laboratory

${ }^{3}$ Environmental Science and Waste Technology Group, Los Alamos National Laboratory

'Science Applications, Inc., 122 Longview Drive, White Rock, NM 87544 


\section{DISCLAmitr}

Portions of this document may be illegible in electronic image produets. Images are produced from the best available original document. 


\section{CONTENTS}

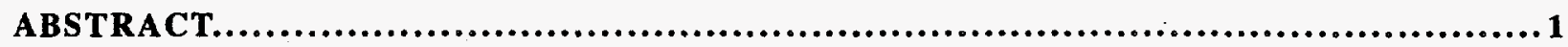

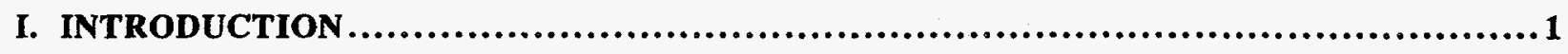

II. HYDROGEOLOGIC SETTING OF MORTANDAD CANYON $\ldots \ldots \ldots \ldots \ldots \ldots \ldots \ldots \ldots \ldots \ldots$

III. METHODOLOGY ......................................................................

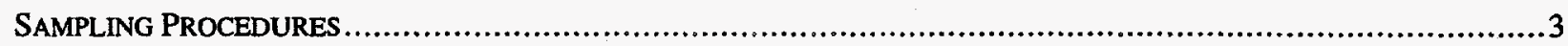

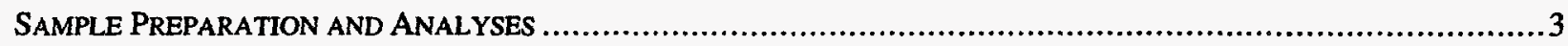

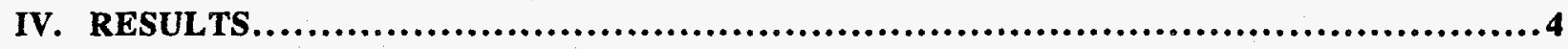

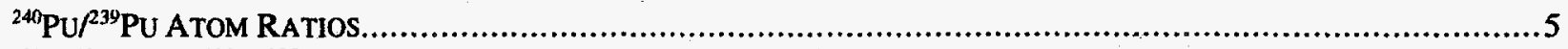

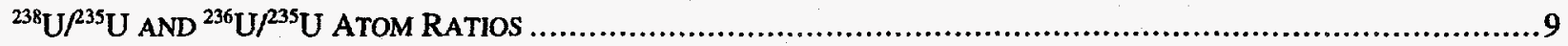

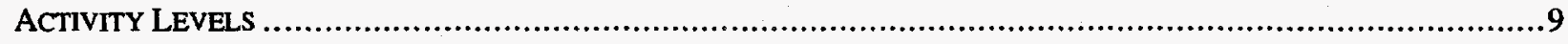

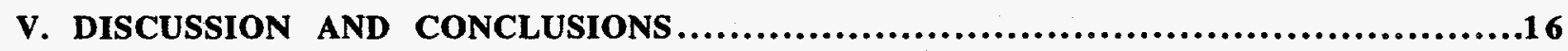

VI. RECOMMENDATIONS FOR FUTURE WORK...................................17

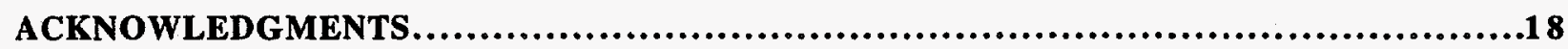

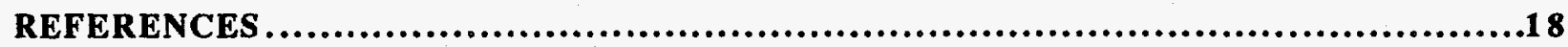

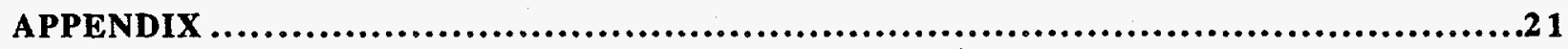

\section{Figures}

Figure 1. Comparison of Mortandad Canyon plutonium atom ratios with the range for global fallout.. 6

Figure 2. Map view of plutonium atom ratios......................................................................

Figure 3. Comparison of Mortandad Canyon uranium atom ratios with natural uranium.................11

Figure 4. Map view of uranium atom ratios..............................................................................12

\section{TABLeS}

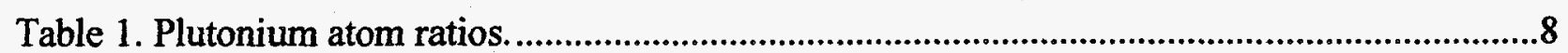

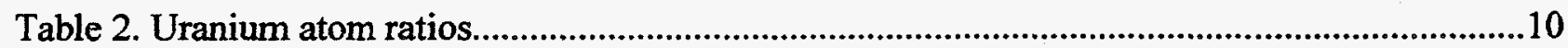

Table 3. Summary interpretation of isotopic data. ......................................................... 13

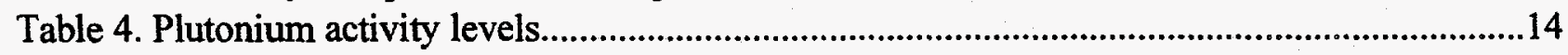

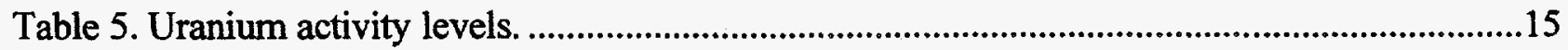




\title{
SURVEY OF PLUTONIUM AND URANIUM ATOM RATIOS AND ACTIVITY LEVELS IN MORTANDAD CANYON
}

\author{
by \\ B. M. Gallaher, D. W. Efurd, D. J. Rokop, T. M. Benjamin, and A. K. Stoker
}

\begin{abstract}
For more than three decades, Mortandad Canyon has been the primary release area of treated liquid radioactive waste from the Los Alamos National Laboratory (Laboratory). In this survey, six water samples and seven stream sediment samples collected in Mortandad Canyon were analyzed by thermal ionization mass spectrometry to determine the plutonium and uranium activity levels and atom ratios. By measuring the ${ }^{240} \mathrm{Pu} /{ }^{239} \mathrm{Pu}$ atom ratios, the Laboratory plutonium component was evaluated relative to that from global fallout. Measurements of the relative abundance of ${ }^{235} \mathrm{U}$ and ${ }^{236} \mathrm{U}$ were also used to identify non-natural components. The survey results indicate that the Laboratory plutonium and uranium concentrations in waters and sediments decrease relatively rapidly with distance downstream from the major industrial sources. Plutonium concentrations in shallow alluvial groundwater decrease by approximately 1000-fold along a 3000-ft distance. At the Laboratory downstream boundary, total plutonium and uranium concentrations were generally within regional background ranges previously reported. Laboratory-derived plutonium is readily distinguished from global fallout in on-site waters and sediments. The isotopic ratio data indicate offsite migration of trace levels of Laboratory plutonium in stream sediments to distances approximately two miles downstream of the Laboratory boundary.
\end{abstract}

\section{INTRODUCTION}

Mortandad Canyon has been used for disposal of liquid radioactive waste from the Los Alamos National Laboratory (Laboratory) since 1963. Additional contributions of radioactivity to the canyon may have occurred from wastewater releases and spills from other Laboratory technical areas (TAs) within the drainage. Surface water flowing in lower Mortandad Canyon enters San Ildefonso Pueblo land. Because of the location of Mortandad Canyon with regard to areas of public access, the release of plutonium and other radionuclides is of concern to the Laboratory and the public. Thus, for more than three decades, the Laboratory's Environmental Surveillance Program (ESP) has tested water and sediment samples from the canyon floor (ESP 1996). The analytical results obtained from these monitoring activities are adequate to evaluate health risks. However, when concentrations of radioactivity are low, the ESP analytical methods do not provide the resolution necessary to fully quantify the 
Laboratory's impact on the environment, particularly for plutonium and uranium.

Standard quantitative measurements of plutonium and uranium (respectively, alpha pulse height spectrometry and chemical methods) are unable to distinguish Laboratory-derived components in environmental samples from background levels of these elements. Unlike other radionuclides that are unambiguously associated with Laboratory operations, both plutonium and uranium are ubiquitous in the surface environment, and their presence at low concentrations cannot be exclusively related to a single source, such as the Laboratory. Uranium is abundant naturally in soils and waters, and plutonium has been deposited worldwide via global fallout from atmospheric testing of nuclear devices and from satellite re-entry and burnup in the Earth's atmosphere.

In this survey we analyze waters and sediments in Mortandad Canyon using specialized mass spectrometry analytical methods. The "fingerprinting" of plutonium and uranium by measuring the isotopic composition by mass spectrometry is capable of distinguishing and quantifying the contributions of the different sources of these radionuclides in a single sample (Efurd et al. 1994, 1995). In addition, the mass spectrometry analyses provide lower analytical detection limits than conventional methods. Both the isotopic composition and the activity-level data will be used in refining the concepts of how these constituents move through the environment.

\section{HYDROGEOLOGIC SETTING OF MORTANDAD CANYON}

Mortandad Canyon has been the subject of numerous hydrogeologic investigations since the early $1960 \mathrm{~s}$. A number of these studies were conducted by the U.S. Geological Survey (USGS) and summarized by Devaurs and Purtymun (1985), Stoker et al. (1991), and Purtymun (1995). The following text is taken from Purtymun (1995):

"Mortandad Canyon heads along the western edge of the plateau at an elevation of about $7500 \mathrm{ft}$ and has a drainage area of $1.8 \mathrm{sq}$ mi west of the boundary between the Laboratory and San Ildefonso Pueblo. The alluvium is derived from the weathering of the Bandelier Tuff, and consists of silt, sand, and gravel. Perennial surface flow occurs in the midreach of the canyon with the release of wastewater from TA-46 and treated effluent from the treatment plant at TA-50. Mortandad Canyon is the major release area for treated radioactive effluents. The surface water, effluents, and storm runoff recharge an aquifer perched in the alluvium. The recharge is only sufficient to maintain an aquifer of limited extent. The surface flow and water in the alluvium is contained within the Laboratory due to the small drainage area and thick section of unsaturated alluvium."

Off-site migration of water-borne contaminants would most likely occur from the downward percolation of effluent to deeper groundwater or from stormwater runoff. Depth to the shallow groundwater rapidly increases downstream below well MCO-4. Depths to water in wells tested for 
this survey range from approximately $3 \mathrm{ft}$ at well MCO-4 to $36 \mathrm{ft}$ at MCO-6 to $42 \mathrm{ft}$ at MCO-7.5. The main aquifer for Los Alamos, which is in the Puye and Santa Fe Formations, underlies the canyon floor by approximately $900 \mathrm{ft}$. No saturation has been found between the base of the alluvium and the top of the main aquifer (Baltz et al. 1963). Streamflow off-site occurs very infrequently. Streamflow at the Laboratory's eastern boundary in Mortandad Canyon has been continuously monitored since 1995 (USGS station 08313204). In the two years of record, there has been no recorded flow (Shaull et al. 1996a, b).

\section{METHODOLOGY}

\section{Sampling Procedures}

Samples of surface water, shallow groundwater, and stream channel sediments were collected for this survey. All water samples were collected on-site at the Laboratory, while sediment samples were collected both on-site and off-site. The surface water sample was collected at Gaging Station 1 (GS-1 in this report, USGS station 08313200). Streamflow at this location is typically dominated by discharges from the TA-50 treatment plant, located approximately one-half mile upstream. Five groundwater samples were collected from shallow wells completed in the canyon bottom alluvium. Sediments were collected from the active stream channel at seven locations.

Samples from the least contaminated lower portions of the watershed were collected at different time periods than the samples collected at the most contaminated locations near the TA- 50 outfall. New disposable latex gloves were worn by sampling personnel at each location. All samples were stored in ice chests and transferred to the Mass Spectrometry Laboratory under full chainof-custody procedures.

Stream sediment samples were collected from transects across the active streambed channel at the 0 - to 3-cm (0- to 1-in.) depth using clean-wrapped disposable plastic scoops. Emphasis was on collecting the finer grained materials, avoiding collection of organic matter, cobbles, and pebbles. The sediments were poured into labeled 250 - or $500-\mathrm{ml}$ polybottles.

Each of the five alluvial monitoring wells sampled in Mortandad Canyon are equipped with dedicated Teflon ${ }^{\mathrm{TM}}$ bladder pumps. The equivalent of three casing volumes of water was purged from each well before collection of the groundwater samples. This purging was done to collect representative water samples by removing any stagnant water from the well casings. Water was pumped directly from the pump discharge tubing into labeled $500-\mathrm{ml}$ polybottles. The surface water sample at Gaging Station 1 was hand dipped from the flowing stream using a clean polybottle. Samples were acidified with nitric acid within three hours of collection. The acid prevents the actinides from adhering to the walls of the container. The protocol used to stabilize the samples for this study is comparable to the protocol used by the Environmental Protection Agency (EPA). All of the water samples were submitted for analyses as whole (unfiltered) samples.

\section{Sample Preparation and Analyses} Environmental samples collected for this study were submitted to the Los Alamos Clean Chemistry and Mass Spectrometry Laboratory for thermal ionization mass 
spectrometric (TIMS) analyses. Most of the actinide activity levels and all of the atom ratios reported in this report were derived from the TIMS analyses. ${ }^{238} \mathrm{Pu}$ activity levels were analyzed using alpha pulse height spectrometry by the Environmental Chemistry Group. The procedures for TIMS analysis of uranium and plutonium were developed by the Mass Spectrometry Laboratory and are described in detail in Efurd et al. (1993a). The TIMS analyses procedures are briefly summarized here.

TIMS analyses sample preparation and mass spectrometry are both performed in class-100 clean rooms specifically designed for ultra-low-level environmental actinide analyses. During the sample preparation, sediment and soil samples initially are digested with ultra-pure acids. Both waters and soils are then traced with precisely known amounts of reference standards, separated into elements by anion exchange chromatography, and electroplated on mass spectrometry filaments to produce an ionization source for TIMS analysis. The filament is then inserted into a thermal ionization mass spectrometer that measures the relative abundance of the isotopes of interest compared with the reference standards.

The TIMS analyses procedure allows for the quantification of the isotopic composition of the plutonium in the sample, for example, ${ }^{240} \mathrm{Pu} /{ }^{239} \mathrm{Pu}$. Measurement of the ${ }^{240} \mathrm{Pu} /{ }^{239} \mathrm{Pu}$ atom ratio in samples can be used to distinguish the global fallout component from the Laboratory component(s). The following uranium isotopes are determined: ${ }^{234} \mathrm{U},{ }^{235} \mathrm{U},{ }^{236} \mathrm{U}$, and ${ }^{238} \mathrm{U}$. The ${ }^{238} \mathrm{U} /{ }^{235} \mathrm{U}$ atom ratio can be used to distinguish the naturally occurring uranium from its anthropogenically produced components, i.e., enriched uranium and/or depleted uranium. The enriched and depleted forms of uranium result from the processing of natural uranium to selectively increase (or decrease) the abundance of ${ }^{235} \mathrm{U}$ relative to ${ }^{238} \mathrm{U}$. Enriched uranium is processed uranium containing more than 0.72 atom percent, the natural abundance of ${ }^{235} \mathrm{U}$; depleted uranium contains less than 0.72 percent ${ }^{235} U$. The abundance of ${ }^{235} \mathrm{U}$ in highly enriched uranium may be greater than 90 percent, while the ${ }^{235} \mathrm{U}$ abundance in highly depleted uranium may be on the order of 0.25 percent. The ${ }^{236} \mathrm{U}$ isotope does not exist in nature and its presence unambiguously indicates an anthropogenic component. The ${ }^{236} \mathrm{U}$ isotope is formed through exposure of ${ }^{235} \mathrm{U}$ to a neutron source.

\section{RESULTS}

Tables 1 through 6 present the results of the analysis of the six water samples and seven sediment samples from Mortandad Canyon. The sample numbers in Table A-1 in the Appendix are the alphanumeric sequences used by the Mass Spectrometry Laboratory personnel to uniquely identify each sample. The atom ratios were measured by TIMS analysis. The standard deviations of the atom ratios are at the 1 sigma level. These standard deviations propagate the errors associated with measuring the count rate of each isotope and the measurement backgrounds. Data have been corrected for processing blanks. The uncertainty associated with measurements of the processing blanks is included in the uncertainty term reported for the atom ratios. The standard deviation does not include any errors associated with sample inhomogeneity. The plutonium and uranium activity levels were determined by 
multiplying the number of atoms of each isotope per liter or gram measured by TIMS analysis by the appropriate half-life and decay constants. The uranium mass equivalent concentrations were determined by multiplying the number of atoms by the appropriate specific activities.

\section{${ }^{240} \mathrm{Pu} /{ }^{239}$ Pu Atom Ratios}

The primary source of plutonium in most locations in New Mexico is global fallout from atmospheric testing of nuclear devices. Areas surrounding the Laboratory may contain plutonium from global fallout or a mixture of Laboratory-related plutonium and global fallout. The plutonium concentrations and isotopic composition of global fallout varies from location to location. Krey and Hardy (1976) measured the ${ }^{240} \mathrm{Pu} /{ }^{239} \mathrm{Pu}$ atom ratio in global fallout to be 0.176 with a standard deviation of 0.014 and ranges from 0.12 to 0.21 around the world. In two separate studies, Efurd et al. $(1994,1995)$ measured 47 soil samples from locations in Colorado believed to be representative of global fallout. The ${ }^{240} \mathrm{Pu} /{ }^{239} \mathrm{Pu}$ atom ratios in the Colorado samples ranged from a low of $0.143 \pm 0.006$ to a high of $0.183 \pm 0.073$. Efurd et al. (1995) concluded that the most representative ${ }^{240} \mathrm{Pu} /{ }^{239} \mathrm{Pu}$ atom ratio for the Denver area was $0.169 \pm 0.005$. Studies to evaluate the range in ${ }^{240} \mathrm{Pu} /{ }^{239} \mathrm{Pu}$ atom ratios in global fallout at Los Alamos are not complete. For this study, it is assumed that the ${ }^{240} \mathrm{Pu} /{ }^{239} \mathrm{Pu}$ atom ratio of $0.18 \pm 0.02$ represents global fallout at Los Alamos.

Environmental samples with ${ }^{240} \mathrm{Pu} /{ }^{239} \mathrm{Pu}$ atom ratios significantly lower than global fallout usually indicate the presence of a non-fallout component of plutonium. There are multiple potential sources of Laboratoryrelated plutonium in the Mortandad Canyon drainage system. Thus, the isotopic data may not immediately yield the specific source of the non-fallout component, without extensive environmental sampling or knowledge of site-specific operations.

The ${ }^{240} \mathrm{Pu} /{ }^{239} \mathrm{Pu}$ atom ratios for the Mortandad Canyon samples are compared against the ratio ranges for global fallout in Figure 1, and listed in Table 1. The figure illustrates for each station the calculated atom ratio plus its three standard deviations uncertainty (approximate 99 percent confidence interval, 3 sigma). Samples with higher activities of plutonium generally yield more robust measurements of the isotopic ratios, i.e., lower uncertainties. If the upper limit of the ratio plus uncertainty is lower than the global fallout range, then the data indicate the presence of a local source of plutonium. Figure 2 displays the ${ }^{240} \mathrm{Pu} /{ }^{239} \mathrm{Pu}$ atom ratios in a map of the drainage system.

The ${ }^{240} \mathrm{Pu} /{ }^{239} \mathrm{Pu}$ atom ratios of the water samples range from a low of $0.066 \pm 0.007$ at MCO-4 to highs of $0.114 \pm 0.032$ at MCO-6 and $0.093 \pm 0.080$ at MCO-7.5. All the water stations except well MCO-7.5 indicate a significant component of Laboratory plutonium, assuming that the range of global fallout is accurately represented in Figure 2. Factoring in uncertainty, the ${ }^{240} \mathrm{Pu} /{ }^{239} \mathrm{Pu}$ atom ratio at MCO-7.5 may be as large as 0.172 , which is indistinguishable at the 99 percent confidence level from global fallout (Krey 1976). The ${ }^{240} \mathrm{Pu} /{ }^{239} \mathrm{Pu}$ atom ratio in the sample collected at the surface water station GS-1 is similar to that from the groundwater at MCO-4, the closest well to GS-1 that was sampled. 
Mortandad Canyon Pu Ratios (ratio +3 sigma uncertainty)

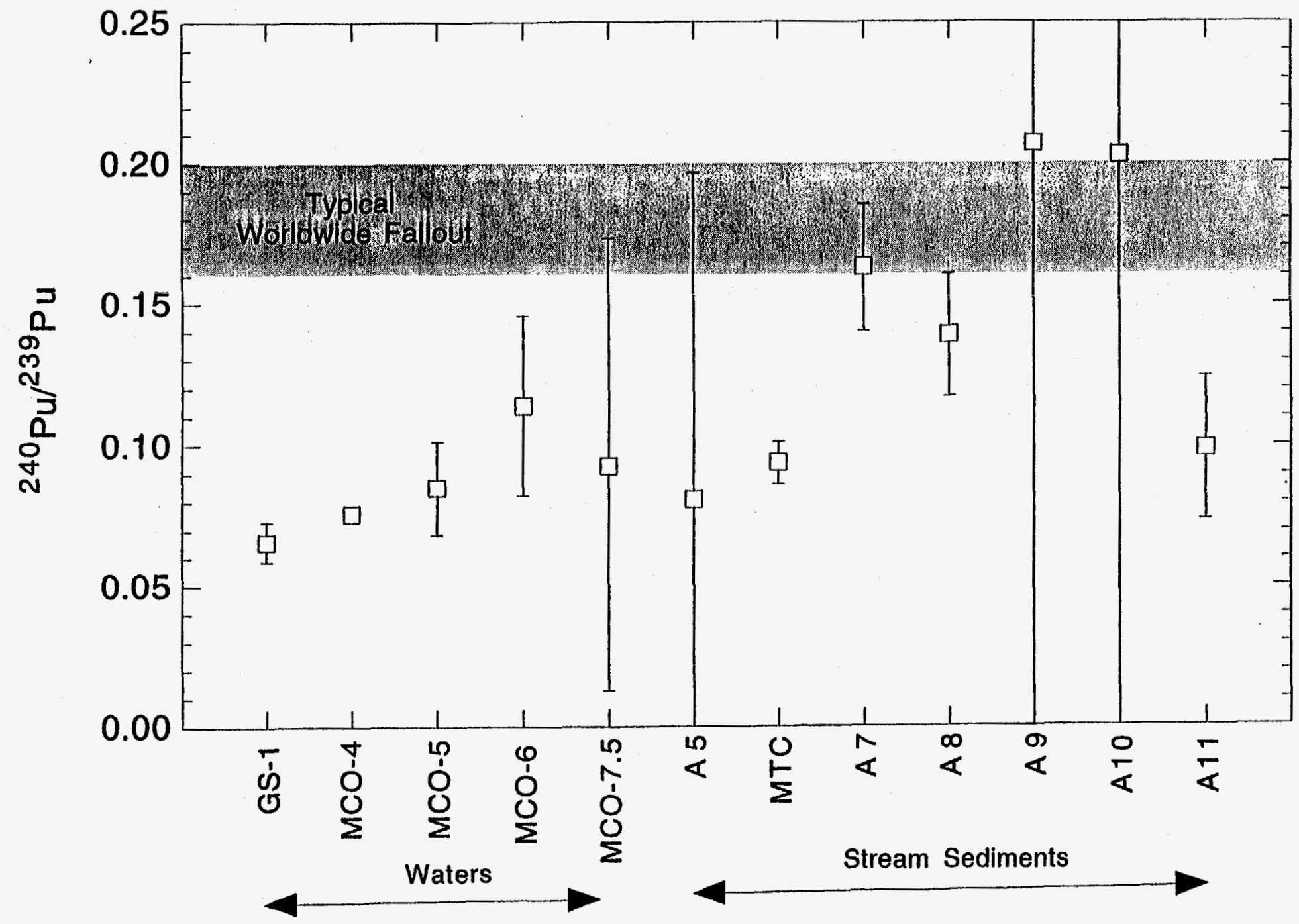


- Surface or Groundwater Station

- Sediment Station

-...- LANL Boundary

$0.163{ }^{240} \mathrm{Pu} /{ }^{239} \mathrm{Pu}$ Isotope Ratios

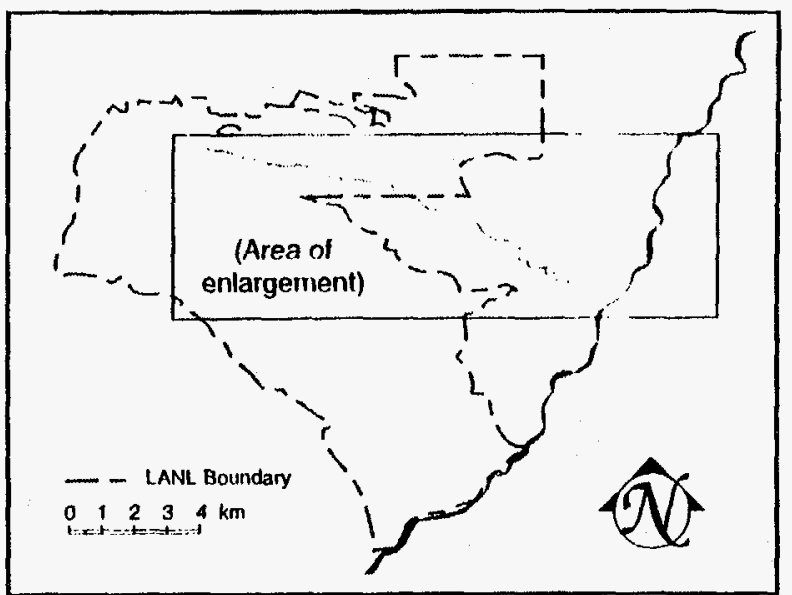

BDL Below Detection Limit

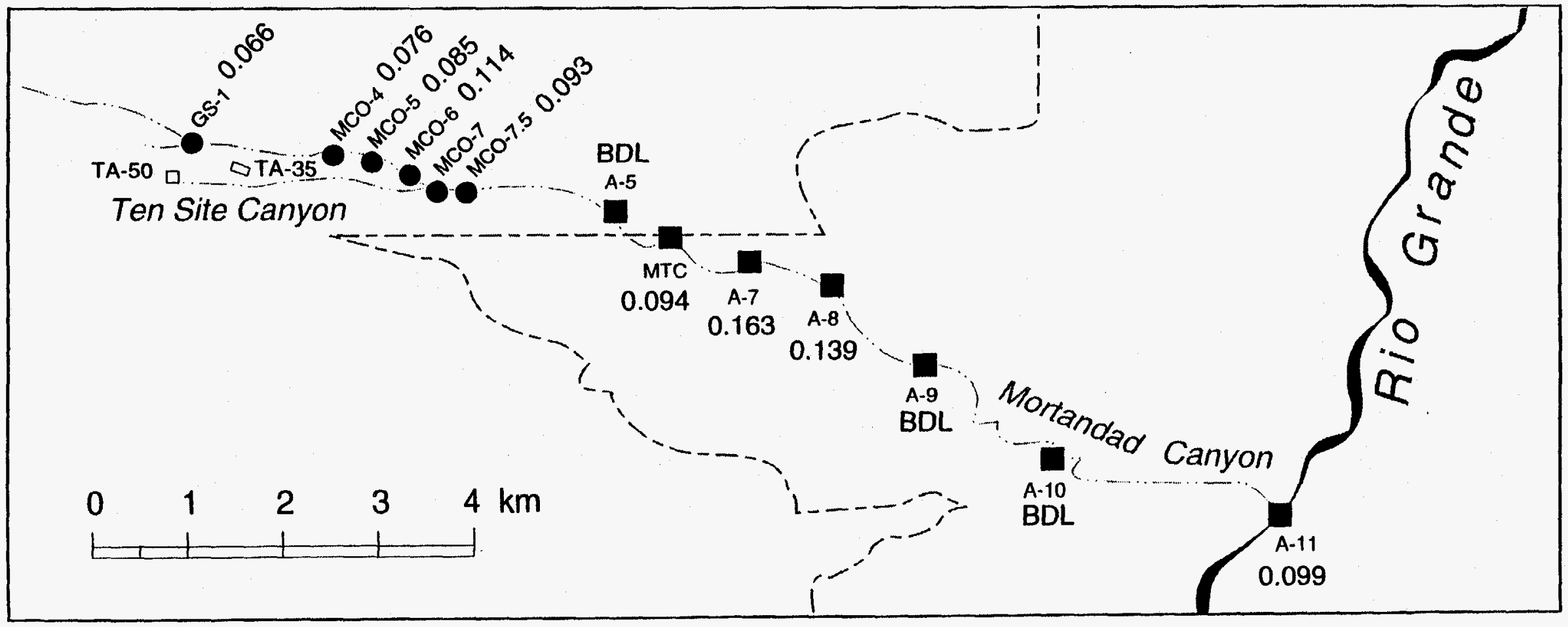

Figure 2. Map view of plutonium atom ratios. 


\begin{tabular}{|c|c|c|c|c|c|}
\hline \multicolumn{5}{|c|}{ Table 1. Plutonium Atom Ratios } & \\
\hline & $\begin{array}{c}\text { A tom } \\
\text { Ratio } \\
{ }^{240} \mathrm{Pu} /{ }^{239} \mathrm{Pu} \\
\end{array}$ & $\begin{array}{c}\text { Sigma } \\
(\%)\end{array}$ & $\underset{{ }^{241} \mathrm{Pu} /{ }^{239} \mathrm{Pu}}{\text { Ratio }}$ & $\underset{(\%)}{\text { Sigma }}$ & \\
\hline GS-1 & 0.066 & $3.6 \%$ & \multirow{5}{*}{0.003} & \multirow{5}{*}{$8.4 \%$} & \\
\hline $\mathrm{MCO}-4$ & 0.076 & $1.2 \%$ & & & \\
\hline MCO-5 & 0.085 & $6.5 \%$ & & & \\
\hline $\mathrm{MCO}-6$ & 0.114 & $9.3 \%$ & & & \\
\hline \multirow[t]{2}{*}{ MCO-7.5 } & 0.093 & $28.7 \%$ & & & \\
\hline & $\begin{array}{c}\text { Atom } \\
\text { Ratio } \\
{ }^{240} \mathbf{P u} /^{239} \mathbf{P u} \\
\end{array}$ & $\begin{array}{c}\text { Sigma } \\
(\%)\end{array}$ & $\underset{{ }^{241} \mathrm{Pu} /{ }^{239} \mathbf{P u}}{\text { Rtom }}$ & $\underset{(\%)}{\text { Sigma }}$ & \\
\hline $\mathrm{A}-5$ & 0.081 & UNR & & & \\
\hline MTC & 0.094 & $2.7 \%$ & 0.003 & $27.6 \%$ & \\
\hline A-7 & 0.163 & $4.6 \%$ & & & \\
\hline A-8 & 0.139 & $5.2 \%$ & & & \\
\hline A-9 & 0.207 & $348 \%$ LNR & & & \\
\hline A-10 & 0.203 & $983 \%$ UNR & & & \\
\hline A-11 & 0.099 & $8.5 \%$ & 0.005 & $224.5 \%$ & UMIR \\
\hline
\end{tabular}

Note: Atom ratios shaded and marked with UNR are considered to be unresolved due to the greater uncertainty of the measurements at very low concentrations (approximate 99 percent confidence interval, 3 sigma).

Along the reach from well $\mathrm{MCO}-4$ to $\mathrm{MCO}$ 6 , the ${ }^{240} \mathrm{Pu} /{ }^{239} \mathrm{Pu}$ ratios in groundwater appear to gradually increase towards the fallout range. The specific cause is undetermined, but some possibilities include: changing isotopic ratios in Laboratory sources over time (Penrose et al. 1990) or the dilution of the Laboratory isotopic signature through the addition of global fallout plutonium to the groundwater, either naturally by infiltration processes or artificially through the drilling of the boreholes (i.e., mechanically carrying fallout plutonium from the surface downward to the groundwater zone). Additional analyses and field work would likely have to be conducted to determine the cause in this apparent shift in isotopic ratios.
${ }^{240} \mathrm{Pu} /{ }^{239} \mathrm{Pu}$ ratios in sediment stations $\mathrm{A}-5$, $A-9$, and A-10 were unresolvable at the 99 percent confidence level due to the large uncertainties in the individual isotope measurements. ${ }^{240} \mathrm{Pu}$ activity levels at these locations are near or below analytical detection limits. ${ }^{240} \mathrm{Pu} /{ }^{239} \mathrm{Pu}$ ratios at stations MTC, A-8, and A-11 indicate a non-global fallout component of plutonium. Factoring in the uncertainty, the ${ }^{240} \mathrm{Pu} /{ }^{239} \mathrm{Pu}$ ratio at station A-7 is indistinguishable from global fallout. The data indicate off-site migration of Laboratory plutonium as measured in stream sediments to approximately State Route 4 near station A-8. Both the isotopic ratios and the activity levels indicate the presence of only trace levels of global fallout plutonium downstream of State Route 4 to station A-11 at the Rio Grande. The Laboratory component of plutonium 
indicated at station A-11 alongside the Rio Grande appears to be derived from a different source than Mortandad Canyon. The Laboratory plutonium was most likely introduced to the Rio Grande at an upstream location, most reasonably via Los Alamos Canyon, and deposited in the flood plain area near the confluence with Mortandad Canyon.

\section{${ }^{238} U{ }^{235} U$ AND ${ }^{236} U / /^{235} U$ ATOM RATIOS} The atom ratio of ${ }^{238} \mathrm{U}$ to ${ }^{235} \mathrm{U}$ in naturally occurring uranium is a constant 137.8 (Efurd et al. 1993b). This ratio in Mortandad Canyon waters ranged from 84.2 to 138.2 (Table 2). The most upstream of the water samples (GS-1, MCO-4, MCO-5, MCO-6) measured in Mortandad Canyon were enriched in ${ }^{235} \mathrm{U}$, reflecting Laboratory influences. Waters analyzed from wells MCO-7 and MCO-7.5 showed ratios consistent with natural uranium. As shown in Figures 3 and 4, this recovery to natural abundance at well MCO-7 occurs near the confluence of Ten Site Canyon.

The ${ }^{238} \mathrm{U} /{ }^{235} \mathrm{U}$ atom ratio in Mortandad Canyon sediment samples ranged from 136.1 to 144.5. All of the samples reflect natural compositions except for station A-7, which is depleted in ${ }^{235} \mathrm{U}$. Laboratory-derived uranium is generally not identifiable in sediments by analysis of the ${ }^{238} \mathrm{U} /{ }^{235} \mathrm{U}$ atom ratio, presumably because the sediment contains abundant natural uranium that obscures the anthropogenic signatures. The overall spread in the sediment ${ }^{238} U{ }^{235} U$ atom ratio is much smaller than for the water samples.

The source for the depleted uranium at station A-7 might be air deposition from dynamic testing in the southern portion of the Laboratory (Becker 1992). The pattern of data is not consistent with water deposition of the depleted uranium from upstream sources. If the depleted uranium was transported to station A-7 by water, sediments upstream and closer to the Laboratory facilities would tend to be more depleted than at station A-7, a trend that is not observed in the data. Moreover, the water samples collected upstream are isotopically enriched in ${ }^{235} \mathrm{U}$, rather than depleted.

The presence of ${ }^{236} \mathrm{U}$ in the water and sediment samples collected at Mortandad Canyon and the non-natural ${ }^{238} \mathrm{U} /{ }^{235} \mathrm{U}$ atom ratios in the samples indicate that anthropogenic uranium is present. As summarized in Table 3, the presence of anthropogenic uranium is indicated in the waters at GS-1, MCO-4, MCO-5, and MCO-6, and in the sediments collected at the Laboratory boundary at MTC and station A-7. These non-natural isotopic characteristics may prove to be useful in future work to distinguish Mortandad Canyon uranium from other sources.

\section{ACTIVITY LeVels}

Plutonium activity levels are shown in Table 4. Total plutonium $\left({ }^{238+239+240+241} \mathrm{Pu}\right)$ activity levels in the waters range from 0.04 $\mathrm{pCi} / \mathrm{L}$ to $12.5 \mathrm{pCi} / \mathrm{L}$. Plutonium activity levels in waters decrease rapidly below the TA- 50 outfall, declining by approximately three orders of magnitude over the $3000-\mathrm{ft}$ distance between wells MCO-4 and MCO-6. Plutonium is evidently being diluted or progressively removed from the water column in the downstream direction, probably by adsorption onto the aquifer matrix. All of the plutonium activities are 


\begin{tabular}{|c|c|c|c|c|c|c|c|c|c|}
\hline Sample & $\begin{array}{c}{ }^{236} \mathrm{U} \\
\text { Present } \\
? \\
\end{array}$ & $\begin{array}{l}\text { Depleted (D) } \\
\text { or Enriched } \\
(\mathbf{E})^{235} \mathbf{U} \text { ? }\end{array}$ & $\begin{array}{c}\text { Atom } \\
\text { Ratio } \\
{ }^{234} U /{ }^{235} U \\
\end{array}$ & $\begin{array}{l}\text { Sigma } \\
(\%)\end{array}$ & $\begin{array}{l}\text { Atom Ratio } \\
{ }^{236} \mathbf{U} /{ }^{235} \mathbf{U}\end{array}$ & $\underset{(\%)}{\text { Sigma }}$ & & $\underset{{ }^{238} \mathbf{U} /{ }^{235} \mathbf{U}}{\text { Atom }}$ & $\underset{(\%)}{\text { Sigma }}$ \\
\hline GS-1 & Yes & $\mathrm{E}$ & 0.0107 & $2.88 \%$ & 0.0108 & $1.9 \%$ & & 126.3 & $0.35 \%$ \\
\hline $\mathrm{MCO}-4$ & Yes & E & 0.0135 & $1.82 \%$ & 0.0193 & $0.9 \%$ & & 84.2 & $0.35 \%$ \\
\hline MCO-5 & Yes & $\mathrm{E}$ & 0.0127 & $1.52 \%$ & 0.0148 & $2.7 \%$ & & 112.7 & $0.35 \%$ \\
\hline MCO-6 & Yes & $\mathrm{E}$ & 0.0130 & $1.16 \%$ & 0.0149 & $1.0 \%$ & & 117.2 & $0.35 \%$ \\
\hline MCO-7 & & & 0.0088 & $2.86 \%$ & 0.0001 & $57.5 \%$ & UNR & 136.8 & $0.40 \%$ \\
\hline MCO-7.5 & & & 0.0083 & $2.25 \%$ & 0.0000 & $164.3 \%$ & UNR & 138.2 & $0.35 \%$ \\
\hline A-5 & & & 0.0077 & $1.69 \%$ & 0.0001 & $60.1 \%$ & UNR & 137.5 & $0.35 \%$ \\
\hline MTC & Yes & & 0.0079 & $3.81 \%$ & 0.0004 & $20.5 \%$ & & 138.5 & $0.39 \%$ \\
\hline A-7 & Yes & D & 0.0077 & $1.47 \%$ & 0.0003 & $13.0 \%$ & & 144.5 & $0.35 \%$ \\
\hline A-8 & & & 0.0074 & $1.99 \%$ & 0.0060 & $148.5 \%$ & UNR & 138.5 & $0.35 \%$ \\
\hline A-9 & & & 0.0076 & $2.59 \%$ & 0.0000 & $825.6 \%$ & GINR & 138.1 & $0.35 \%$ \\
\hline A-10 & & & 0.0075 & $2.39 \%$ & 0.0001 & $69.3 \%$ & UNR & 136.7 & $0.35 \%$ \\
\hline A-11 & & & 0.0074 & $1.89 \%$ & 00001 & $71.6 \%$ & UNR & 138.8 & $0.35 \%$ \\
\hline
\end{tabular}

Note: Atom ratios shaded and marked with UNR are considered to be unresolved due to the greater uncertainty of the measurements at very low concentrations ( 99 percent confidence interval, 3 sigma). 


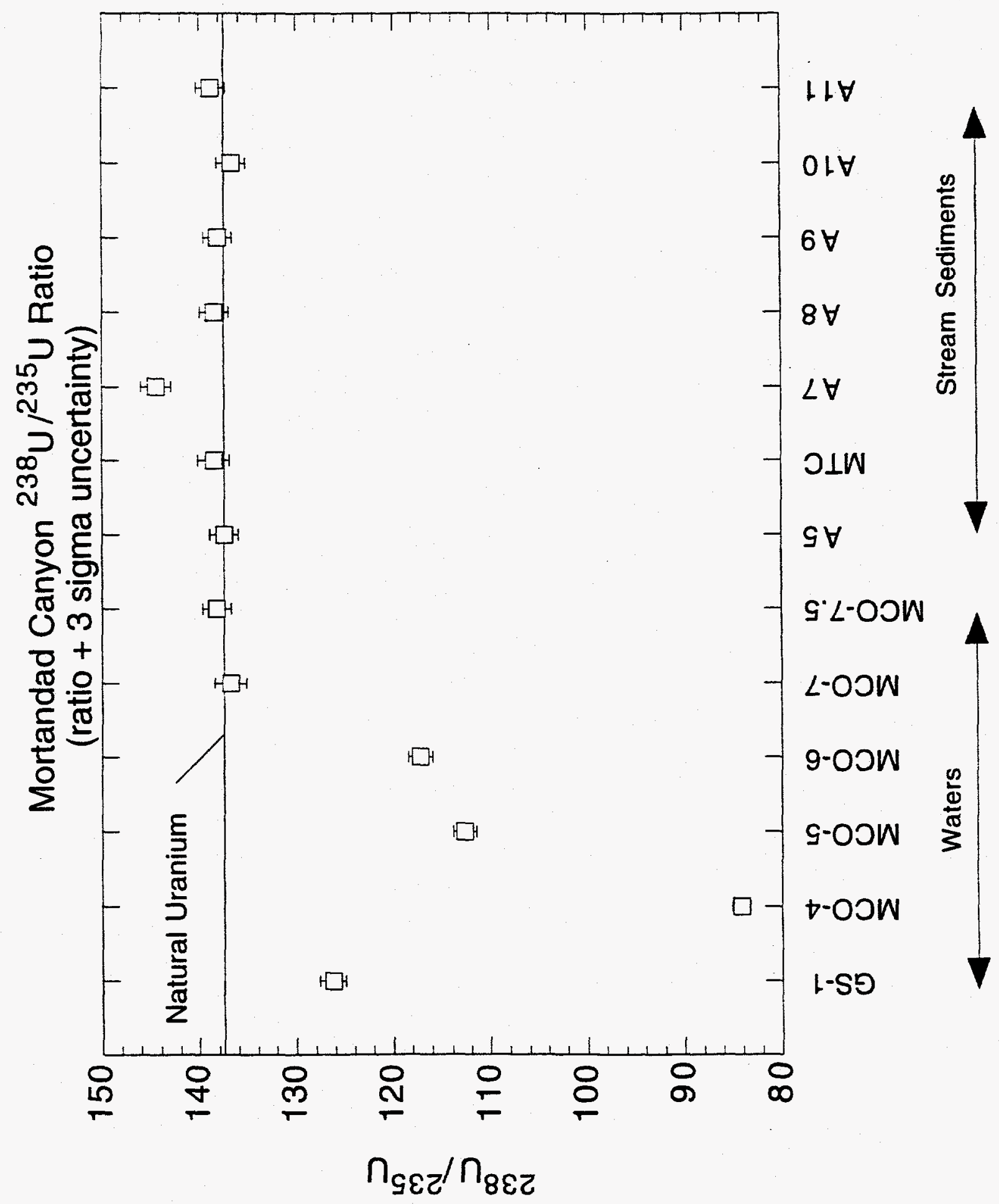

Figure 3. Comparison of Mortandad Canyon uranium atom ratios with natural uranium. 
- Surface or Groundwater Station

- Sediment Station

- - - - - LANL Boundary

$138{ }^{238} \mathrm{U} /{ }^{235} \mathrm{U}$ Isotope Ratios
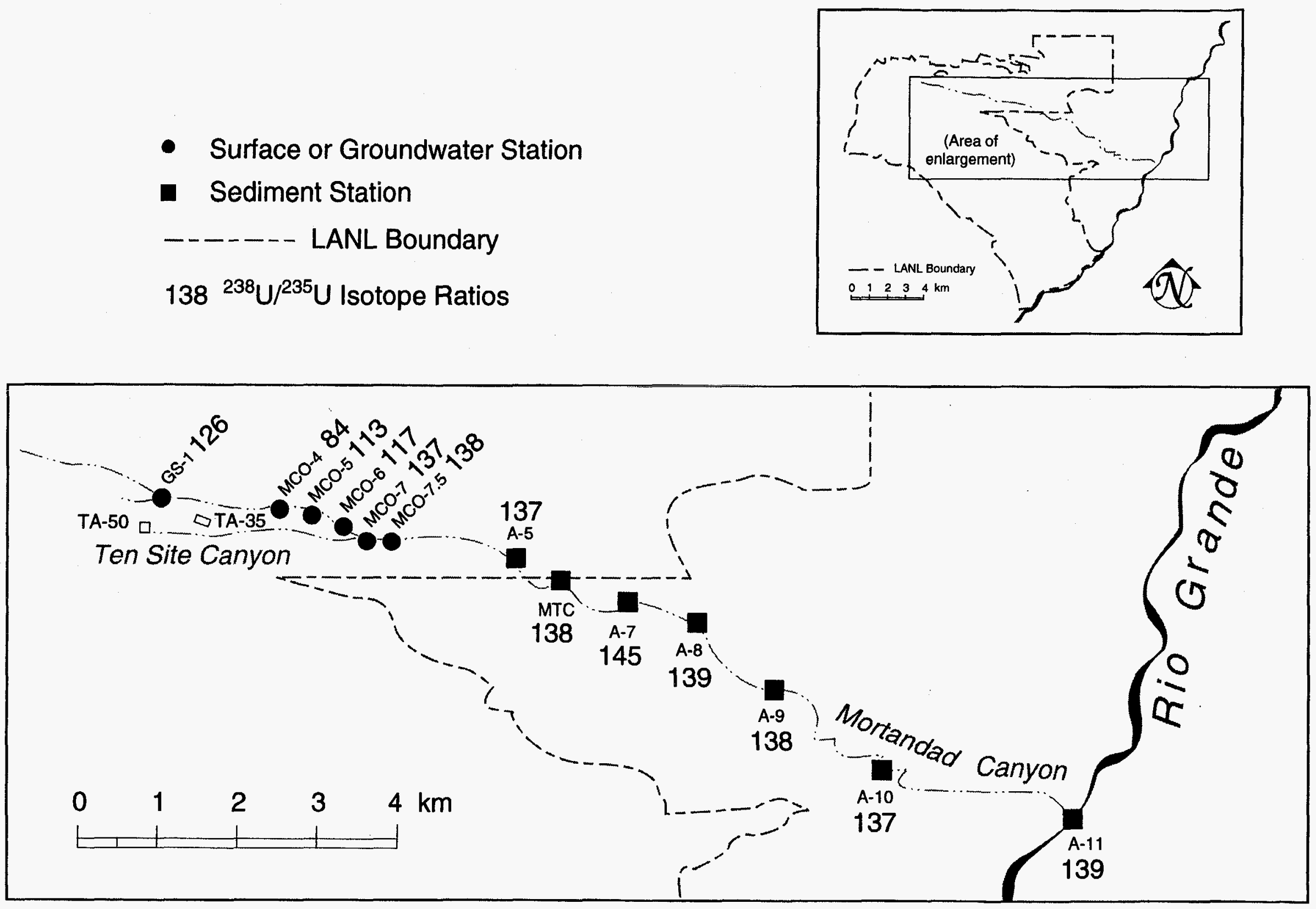

Figure 4. Map view of uranium atom ratios. 


\begin{tabular}{|c|c|c|c|}
\hline Sample & $\begin{array}{l}\text { Laboratory } \mathrm{Pu} \\
\text { Indicated? } \\
\text { (99\% confidence) }\end{array}$ & $\begin{array}{l}{ }^{236} \text { U Present? } \\
\text { (99\% confidence) }\end{array}$ & $\begin{array}{c}\text { Depleted (D) or Enriched }(\mathrm{E}) \\
{ }_{235} \mathrm{U} \text { ? } \\
(99 \% \text { confidence })\end{array}$ \\
\hline \multicolumn{4}{|l|}{ Waters } \\
\hline GS-1 & Yes & Yes & $\mathrm{E}$ \\
\hline $\mathrm{MCO}-4$ & Yes & Yes & $\mathrm{E}$ \\
\hline MCO-5 & Yes & Yes & E \\
\hline MCO-6 & Yes & Yes & E \\
\hline $\mathrm{MCO}-7$ & Yes & & \\
\hline MCO-7.5 & & & \\
\hline
\end{tabular}

\section{Sediments}

$\begin{array}{ccc}\text { Mortandad @ MCO-13 } & \text { Unresolved } & \\ \text { (A-5) } & & \\ \text { MTC } & \text { Yes } & \text { Yes } \\ \text { A-7 } & & \text { Yes } \\ \text { A-8 } & \text { Yes } & \\ \text { Mortandad @ SR4 } & \text { Unresolved } & \\ \text { (A-9) } & & \\ \text { A-10 } & \text { Unresolved } & \\ \text { Mortandad @ Rio Grande } & \text { Yes } & \\ \text { (A-11) } & & \end{array}$

below the Department of Energy (DOE) Derived Concentration Guide (DCG) limits for public exposure. Although the shallow groundwater in Mortandad Canyon is not used for consumption, a comparison indicates that only the ${ }^{239} \mathrm{Pu}$ activity in well MCO-4 exceeds the DOE plutonium DCG limits for drinking water systems $(1.6 \mathrm{pCi} / \mathrm{L}$ vs. the $\mathrm{DCG}$ of $1.2 \mathrm{pCi} / \mathrm{L}$; DOE 1990).

Total plutonium $\left({ }^{238+239+240+241} \mathrm{Pu}\right)$ activity levels in sediments range over two orders of magnitude from approximately $0.001 \mathrm{pCi} / \mathrm{g}$ to $0.06 \mathrm{pCi} / \mathrm{g}$. ${ }^{238} \mathrm{Pu}$ and ${ }^{239+240} \mathrm{Pu}$ concentrations in sediments are considerably below the Screening Action Levels ( 27 and 24 $\mathrm{pCi} / \mathrm{g}$, respectively) used by the Laboratory's Environmental Restoration Project to trigger possible further investigations or possible cleanup

actions (ER 1997). The combined ${ }^{239+240} \mathrm{Pu}$ activity levels at all of the sediment sampling locations are within the range of regional background levels (upper limit $=0.023 \mathrm{pCi} / \mathrm{g}$ ) established by Purtymun et al. (1987) using alpha pulse height spectrometry.

The total uranium $\left({ }^{234+235+236+238} \mathrm{U}\right)$ activities and equivalent mass concentrations are reported in Table 5. Total uranium activities in the waters range from 0.3 to $3.6 \mathrm{pCi} / \mathrm{L}$ (equivalent to 0.4 to $4.9 \mu \mathrm{g} / \mathrm{L}$ ). In contrast to plutonium, there is a slight increase in uranium levels downstream from wells MCO-4 to MCO-7. The levels, however, sharply decline by a factor of 6 in the 950-ft distance between wells MCO-7 and MCO-7.5. The cause of this decline is undetermined but it may be related to inflow of more dilute water 


\begin{tabular}{|c|c|c|c|c|c|c|c|c|c|}
\hline Waters & $\begin{array}{c}{ }^{238} \mathrm{Pu} \\
\mathrm{pCi} / \mathrm{L}\end{array}$ & $\begin{array}{c}\text { Sigma } \\
(\%)\end{array}$ & $\begin{array}{c}{ }^{239} \mathrm{Pu} \\
\mathrm{pCi} / \mathrm{L}\end{array}$ & $\begin{array}{c}\text { Sigma } \\
(\%)\end{array}$ & $\begin{array}{c}{ }^{240} \mathrm{Pu} \\
\mathrm{pCi} / \mathrm{L}\end{array}$ & $\begin{array}{c}\text { Sigma } \\
(\%)\end{array}$ & & $\begin{array}{r}{ }^{241} \mathrm{Pu} \\
\mathrm{pCi} / \mathrm{L}\end{array}$ & $\begin{array}{c}\text { Sigma } \\
(\%)\end{array}$ \\
\hline GS-1 & 0.465 & $11 \%$ & 0.155 & $2.2 \%$ & 0.038 & $2.9 \%$ & & & \\
\hline MCO-4 & 1.308 & $7.8 \%$ & 1.588 & $0.3 \%$ & 0.441 & $1.2 \%$ & & 9.190 & $8.4 \%$ \\
\hline MCO-5 & 0.077 & $39 \%$ & 0.048 & $1.4 \%$ & 0.015 & $6.4 \%$ & & & \\
\hline MCO-6 & 0.012 & $250 \%$ & 0.013 & $2.9 \%$ & 0.006 & $8.9 \%$ & & & \\
\hline MCO-7 & 0.012 & $250 \%$ & - & - & - & - & & --- & -- \\
\hline MCO-7.5 & 0.037 & $81 \%$ & 0.006 & $4.4 \%$ & 0.002 & $28.4 \%$ & & & \\
\hline Sediments & $\begin{array}{c}{ }^{238} \mathrm{Pu} \\
\mathrm{pCi} / \mathrm{g}\end{array}$ & $\begin{array}{c}\text { Sigma } \\
(\%)\end{array}$ & $\begin{array}{c}{ }^{239} \mathrm{Pu} \\
\mathrm{pCi} / \mathrm{g} \\
\end{array}$ & $\begin{array}{c}\text { Sigma } \\
(\%)\end{array}$ & $\begin{array}{c}{ }^{240} \mathrm{Pu} \\
\mathrm{pCi} / \mathrm{g}\end{array}$ & $\begin{array}{c}\text { Sigma } \\
(\%)\end{array}$ & & $\begin{array}{c}{ }^{241} \mathrm{Pu} \\
\mathrm{pCi} / \mathrm{g}\end{array}$ & $\begin{array}{c}\text { Sigma } \\
(\%)\end{array}$ \\
\hline A-5 & 0.005 & $40 \%$ & 0.0004 & $5.3 \%$ & 0.001 & 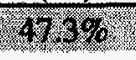 & BDe & & \\
\hline MTC & 0.001 & $100 \%$ & 0.0096 & $0.8 \%$ & 0.0033 & $2.6 \%$ & & 0.0474 & $27.6 \%$ \\
\hline A-7 & 0.019 & $16 \%$ & 0.0066 & $1.5 \%$ & 0.0039 & $4.3 \%$ & & 0.0368 & $64.5 \%$ \\
\hline A-8 & 0.025 & $20 \%$ & 0.0012 & $1.3 \%$ & 0.0006 & $5.1 \%$ & & & \\
\hline A-9 & 0.003 & $33 \%$ & 0.0004 & $8.7 \%$ & 0.0003 & $337 \%$ & BDL & & \\
\hline A-10 & 0.002 & $50 \%$ & 0.0003 & $23.4 \%$ & 0.0002 & $95.4 \%$ & BDL & & \\
\hline A-11 & 0.006 & $17 \%$ & 0.0018 & $1.9 \%$ & 0.0007 & $8.3 \%$ & & 0.0135 & $24.5 \%$ \\
\hline
\end{tabular}

Note: Activity levels shaded and marked with BDL are considered to be below analytical detection limits (approximate 99 percent confidence interval, 3 sigma).

* ${ }^{238} \mathrm{Pu}$ analysis performed using alpha pulse height spectrometry. All other analyses performed using TIMS. 


\begin{tabular}{|c|c|c|c|c|c|c|c|c|c|c|c|}
\hline Waters & $\begin{array}{c}{ }^{234} \mathrm{U} \\
\mathrm{pCi} / \mathrm{L}\end{array}$ & $\begin{array}{c}\text { Sigma } \\
(\%)\end{array}$ & $\begin{array}{c}{ }^{235} \mathrm{U} \\
\mathrm{pCi} / \mathrm{L}\end{array}$ & $\begin{array}{c}\text { Sigma } \\
(\%)\end{array}$ & $\begin{array}{c}{ }^{236} \mathrm{U} \\
\mathrm{pCi} / \mathrm{L}\end{array}$ & $\begin{array}{c}\text { Sigma } \\
(\%)\end{array}$ & & $\begin{array}{c}{ }^{238} \mathrm{U} \\
\mathrm{pCi} / \mathrm{L}\end{array}$ & $\begin{array}{c}\text { Sigma } \\
(\%)\end{array}$ & $\begin{array}{c}\text { Total U } \\
\text { Activity } \\
\text { pCi/L }\end{array}$ & $\begin{array}{c}\text { Total U } \\
\text { Conc. } \\
\mu g / L\end{array}$ \\
\hline GS-1 & 0.1982 & $2.9 \%$ & 0.0064 & $0.3 \%$ & 0.0021 & $1.9 \%$ & & 0.1279 & $0.2 \%$ & 0.335 & 0.4 \\
\hline $\mathrm{MCO}-4$ & 1.3867 & $1.8 \%$ & 0.0356 & $0.3 \%$ & 0.0206 & $0.9 \%$ & & 0.4726 & $0.2 \%$ & 1.916 & 1.4 \\
\hline MCO-5 & 1.2766 & $1.5 \%$ & 0.0349 & $0.3 \%$ & 0.0155 & $2.7 \%$ & & 0.6200 & $0.2 \%$ & 1.947 & 1.9 \\
\hline MCO-6 & 1.9582 & $1.1 \%$ & 0.0522 & $0.3 \%$ & 0.0234 & $1.0 \%$ & & 0.9644 & $0.2 \%$ & 2.998 & 2.9 \\
\hline MCO-7 & 1.9243 & $2.8 \%$ & 0.0755 & $0.3 \%$ & 0.0003 & $57.5 \%$ & BDI & 1.6270 & $0.2 \%$ & 3.627 & 4.9 \\
\hline MCO-7.5 & 0.3282 & $2.2 \%$ & 0.0137 & $0.3 \%$ & 00000 & $416,3 \%$ & BDis. & 0.2974 & $0.2 \%$ & 0.639 & 0.9 \\
\hline Sediments & $\begin{array}{c}{ }^{234} \mathrm{U} \\
\mathrm{pCi} / \mathrm{g}\end{array}$ & $\begin{array}{c}\text { Sigma } \\
(\%)\end{array}$ & $\begin{array}{c}{ }^{235} \mathrm{U} \\
\mathrm{pCi} / \mathrm{g}\end{array}$ & $\begin{array}{c}\text { Sigma } \\
(\%)\end{array}$ & $\begin{array}{c}{ }^{236} \mathrm{U} \\
\mathrm{pCi} / \mathrm{g}\end{array}$ & $\begin{array}{c}\text { Sigma } \\
(\%)\end{array}$ & & $\begin{array}{c}{ }^{238} \mathrm{U} \\
\mathrm{pCi} / \mathrm{g}\end{array}$ & $\begin{array}{c}\text { Sigma } \\
(\%)\end{array}$ & $\begin{array}{c}\text { Total U Activity } \\
\mathrm{pCi} / \mathrm{g}\end{array}$ & $\begin{array}{c}\text { Total U } \\
\text { Conc. } \\
\mu \mathrm{g} / \mathrm{g}\end{array}$ \\
\hline A-5 & 0.2761 & $1.7 \%$ & 0.0125 & $0.3 \%$ & 01000) & $6011 \%$ & BDL & 0.2701 & $0.2 \%$ & 0.559 & 0.8 \\
\hline MTC & 0.4693 & $3.8 \%$ & 0.0206 & $0.3 \%$ & 0.0002 & $20.5 \%$ & & 0.4484 & $0.2 \%$ & 0.938 & 1.3 \\
\hline A-7 & 0.7436 & $1.4 \%$ & 0.0335 & $0.3 \%$ & 0.0003 & $13.0 \%$ & & 0.7632 & $0.2 \%$ & 1.541 & 2.3 \\
\hline A-8 & 0.8383 & $2.0 \%$ & 0.0391 & $0.3 \%$ & 01000 & $-148.5 \%$ & BDI: & 0.8536 & $0.2 \%$ & 1.731 & 2.6 \\
\hline A-9 & 0.3627 & $2.6 \%$ & 0.0166 & $0.3 \%$ & 00000 & 82568 & B101 & 0.3621 & $0.2 \%$ & 0.741 & 1.1 \\
\hline A-10 & 0.5363 & $2.4 \%$ & 0.0247 & $0.3 \%$ & OUMI & $69.9 \%$ & DII & 0.5312 & $0.2 \%$ & 1.092 & 1.6 \\
\hline A-11 & 0.8353 & $1.9 \%$ & 0.0389 & $0.3 \%$ & 0.0001 & $71.6 \%$ & BDL & 0.8501 & $0.2 \%$ & 1.724 & 2.6 \\
\hline
\end{tabular}

$\overline{\text { Note: } \mathrm{BDL}}=$ below analytical detection levels at 3 sigma uncertainty ( $99 \%$ confidence). 
from Ten Site Canyon. ${ }^{236} \mathrm{U}$ is found in detectable concentrations at all of the water stations, except for wells MCO-7 and MCO-7.5. All of the total uranium concentrations shown in Table 5 are considerably below the EPA (1996) proposed drinking water limit of $20 \mu \mathrm{g} / \mathrm{L}$ and the New Mexico ground water standard of $5000 \mu \mathrm{g} / \mathrm{L}$ (NMWQCC 1995).

Total uranium activity levels in sediment samples range from 0.6 to $1.7 \mathrm{pCi} / \mathrm{g}(0.8$ to $2.6 \mu \mathrm{g} / \mathrm{g}$ ). ${ }^{236} \mathrm{U}$ is found at two stations, MTC at the boundary and A-7, in concentrations slightly above detection limits. All of the uranium concentrations in sediments are less than or within the natural background concentration range of 3 to $11 \mu \mathrm{g} / \mathrm{g}$ previously established for regional stream sediments (Purtymun et al. 1987) and for the Bandelier Tuff, parent material for stream sediments in Mortandad Canyon (Crowe et al. 1978, Longmire et al. 1995).

\section{DISCUSSION AND CONCLUSIONS}

Based on the available data, the following conclusions are made concerning plutonium and uranium in the water and sediment samples collected at Mortandad Canyon.

1. ${ }^{240} \mathrm{Pu} /{ }^{239} \mathrm{Pu}$ atom ratios indicate that alluvial groundwater, surface water, and stream sediments below the TA50 outfall contain a component of Laboratory-derived plutonium. The waters below the TA-50 outfall have ${ }^{240} \mathrm{Pu} /{ }^{239} \mathrm{Pu}$ atom ratios that tend to cluster between 0.07 to 0.10 , in contrast with typical ratios of 0.16 to 0.20 resulting from global fallout. This Laboratory-related plutonium isotopic signature is reflected in stream sediments many miles downstream of the major Laboratory sources.

2. The data indicate off-site migration of Laboratory plutonium to approximately State Route 4, as measured in stream sediments. Both the isotopic ratios and the activity levels indicate the presence of only trace levels of global fallout plutonium downstream of State Route 4 to near the Rio Grande. This pattern supports the interpretation that a Laboratory component of plutonium indicated in stream sediments alongside the Rio Grande is most reasonably derived from a different source than Mortandad Canyon. The Laboratory plutonium was most likely introduced to the Rio Grande at an upstream location, most reasonably via Los Alamos Canyon, and deposited in the flood plain area near the confluence with Mortandad Canyon.

3. Upstream of the confluence with Ten Site Canyon, waters in Mortandad Canyon are enriched in ${ }^{235} U$ and contain detectable levels of ${ }^{236} \mathrm{U}$, a non-natural form of uranium. The uranium isotopic signature in this reach is highly unique. Below the confluence with Ten Site Canyon, only natural abundance of the uranium isotopes is found in the waters. Most of the sediment samples contain predominantly 
natural uranium. In contrast with plutonium, the Laboratory-related uranium signatures (enriched in ${ }^{235} \mathrm{U}$ ) in the water upstream of Ten Site Canyon are not reflected in downstream sediments. This is evidently because the sediment contains abundant natural uranium that obscures the anthropogenic signatures. Depleted uranium was detected in a stream sediment sample collected on San Ildefonso Pueblo lands near the Laboratory boundary. The source of the depleted uranium is undetermined. The total uranium concentrations in all of the stream sediments tested are within the range reported for the Bandelier Tuff, parent material for the stream sediments in Mortandad Canyon.

4. Total plutonium and uranium activity levels in all the waters and sediments collected for this survey are less than Screening Action Levels used by the Laboratory's Environmental Restoration Project to trigger further investigations or possible cleanup actions. Although a Laboratory component of plutonium is identified in off-site stream sediments using mass spectrometry, at most off-site stations the net increase in radioactivity over background levels would be difficult to recognize using conventional analytical techniques. Total plutonium concentrations measured in stream sediments at the Laboratory boundary are approximately $0.06 \mathrm{pCi} / \mathrm{g}$ higher than in downstream stations that appear to be unaffected by the Laboratory.
5. Plutonium activity levels in waters decrease rapidly below the TA-50 outfall, declining by approximately 1000-fold over the 3000- $\mathrm{ft}$ distance between wells MCO-4 and MCO-6. An equally dramatic decline in ${ }^{236} \mathrm{U}$ concentrations occurs over the 1000 - $\mathrm{ft}$ distance between wells MCO-6 and MCO-7.

\section{RECOMMENDATIONS FOR FUTURE WORK}

1. Additional testing of sediments on Laboratory and San Ildefonso Pueblo lands is needed to add confidence to the conclusion of off-site migration of Laboratory plutonium. Resampling should be performed at the same sediment locations as in this survey. This verification sampling is needed to minimize the possibility of sampling or Laboratory analysis error. An effort should be made to establish vertical profiles of plutonium ratios in both the active channel and the adjacent overbank deposits.

2. Sediment sampling should be conducted in Mortandad Canyon upstream of where liquid radioactive effluents from TA-50 enter the canyon. In Ten Site Canyon, both shallow groundwater (if present) and stream sediments should be sampled. These results may help delineate the principal source of plutonium and uranium in the watercourse, and help explain the water quality change between wells MCO-6 and MCO-7.5. 
3. To investigate the source of depleted uranium in lower Mortandad Canyon sediments, soil sampling should be conducted on the mesas tops and slopes adjacent to the canyon. If depleted uranium is identified in these areas, then deposition by airborne processes is the probable transport mechanism. The soil samples also should be analyzed for plutonium isotope ratios to evaluate the magnitude of air transport of that element.

4. The unique uranium isotopic signature of waters upstream of Ten Site Canyon may help future studies distinguish Mortandad Canyon waters from other sources. In particular, deeper groundwater should be tested using ultra-clean sampling techniques. The detection of enriched uranium or ${ }^{236} \mathrm{U}$ in deeper zones of saturation will indicate a hydraulic connection with the surface.

\section{ACKNOWLEDGMENTS}

The Environmental Surveillance Program of Los Alamos National Laboratory supported this work. We would like to thank field crew members Max Maes, Jake Martinez, Robert Quintana, and Ramon Naranjo for collecting the environmental samples. Significant analytical support was received from Fred Roensch, Harold Poths, John Chamberlin, and Phil Hemberger. The report benefited greatly from the technical review of William R. J. R. Turney and David Rogers. David Rogers prepared the maps in this report.

\section{REFERENCES}

Baltz, E.H., J.H. Abrahams, and W.D. Purtymun, 1963. Preliminary Report on the Geology and Hydrology of Mortandad Canyon near Los Alamos, New Mexico with Special Reference to Disposal of Liquid Low-Level Radioactive Wastes. U.S. Geological Survey open-file report.

Becker, N.M., 1992. Quantification of Uranium Transport Away From Firing Sites at Los Alamos National Laboratory-A Mass Balance Approach. In: Proceedings of the Symposium of Waste Management, Tucson, AZ, 1-5 March 1992.

Crowe, B.M., G.W. Linn, G. Heiken, and M.L. Bevier, 1978. Stratigraphy of the Bandelier Tuff in the Pajarito Plateau. Los Alamos Scientific Laboratory report LA-7225-MS.

Devaurs, M. and W.D. Purtymun, 1985. Hydrologic Characteristics of the Alluvial Aquifers in Mortandad, Canada del Buey, and Pajarito Canyons. Los Alamos National Laboratory report LAUR-85-4002.

DOE, 1990. Derived Concentration Guides for Air and Water. U.S. Department of Energy Order 5400.5, Radiation Protection of the Public and the Environment, U.S. Department of Energy, Washington, D.C.

Efurd, D.W., H.D. Poths, D.J. Rokop, F.R. Roensch, and R.L. Olsen, 1995. Isotopic Fingerprinting of Plutonium in Surface Soil Samples Collected in 
Colorado. Los Alamos National Laboratory report LA-UR-95-3361.

Efurd, D.W., D.J. Rokop, and F.R. Roensch, 1994. Measurement of ${ }^{240} \mathrm{Pu} /{ }^{239} \mathrm{Pu}$ and ${ }^{241} \mathrm{Pu} /{ }^{239} \mathrm{Pu}$ Atom Ratios in Soil Representative of Global Fallout in Colorado. Los Alamos National Laboratory report LA-UR-94-4200.

Efurd, D.W., D.J. Rokop, and R.E. Perrin, 1993a. Actinide Determination and Analytical Support for Water Chacterization and Treatment Studies at Rocky Flats. Los Alamos National Labortory report LA-UR-93-917.

Efurd, D.W., D.J. Rokop, and R.E. Perrin, 1993b. Characterization of the Radioactivity in Surface-Waters and Sediments Collected at the Rocky Flats Facility. Los Alamos National Laboratory report LA-UR-93-4373.

EPA, 1996. Drinking Water Regulations and Health Advisories, May 1996. US Environmental Protection Agency Office of Water, Washington, D.C.

ER, 1997. Screening Action Levels, http://erproject.Laboratory.gov/erint/Sup pOrgs/dscouncil.htm. Los Alamos National Laboratory Environmental Restoration Project.

Krey, P.W. and E.P. Hardy, 1976. Mass Isotopic Composition of Global Fall-Out Plutonium in Soil. In: Transuranium Nuclides in the Environment. International Atomic Energy Agency, Vienna, pp. 671-678.
Krey, P.W. and E.P. Hardy, C. Pachucki, F. Rourke, J. Coluzza, and W.K. Benson, 1976. Masss Isotopic Composition of Global Fall-Out Plutonium in Soil. In: Proceedings of a Symposium on Transuranium Nuclides in the Environment, San Frncisco, 17-21 November 1975, International Atomic Energy Agency, Vienna.

Longmire, P., S. Reneau, P. Watt, J. Gardner, C. Duffy, and R. Ryti, 1995. Natural Background Geochemistry, Geomorphology, and Pediogenesis of Selected Soil Profiles and Bandelier Tuff, Los Alamos, New Mexico. Los Alamos National Laboratory report LA-12193MS.

NMWQCC, 1995. New Mexico Water Quality Control Commission, Title 20, Chapter 6, Part 3, Santa Fe, New Mexico.

Penrose, W.R., W.L. Polzer, E.H. Essington, D.M. Nelson, and K.A. Orlandini, 1990. Mobility of Plutonium and Americium through a Shallow Aquifer in a Semiarid Region. Environment Science \& Technology, Vol. 24, No. 2, 1990.

Purtymun, W.D., 1995. Geologic and Hydrologic Records of Observation Wells, Test Holes, Test Wells, Supply Wells, Springs, and Surface Water Stations in the Los Alamos Area. Los Alamos National Laboratory report LA12883-MS.

Purtymun, W.D., R.J. Peters, T.E. Buhl, M.N.Maes, and F.H. Brown, 1987.

Background Concentrations of 
Radionuclides in Soils and River Sediments in Northern New Mexico, 1974-1986. Los Alamos National Laboratory report LA-11134-MS.

Shaull, D.A., M.R. Alexander, and R.P. Reynolds, 1996. Surface Water Data at Los Alamos National Laboratory: 1995 Water Year. Los Alamos National Laboratory report LA-13177-PR.

Shaull, D.A., M.R. Alexander, and R.P. Reynolds, C.T. McLean, 1996. Surface Water Data at Los Alamos National Laboratory: 1996 Water Year. Los Alamos National Laboratory report LA13234-PR.

Stoker, A.K., W.D. Purtymun, S.G.

McLin, and M.N. Maes, 1991. Extent of Saturation in Mortandad Canyon. Los Alamos National Laboratory report LAUR-91-1660. 
APPENDIX

\begin{tabular}{|c|c|c|c|c|c|c|}
\hline \multirow[b]{2}{*}{$\begin{array}{c}\text { Sample } \\
\text { Location }\end{array}$} & \multicolumn{6}{|c|}{ TABLE A-1. SAMPLE TYPE AND SIZE } \\
\hline & $\begin{array}{c}\text { Sample } \\
\text { Type }\end{array}$ & Sample Date & $\begin{array}{l}\text { Mass Spec. } \\
\text { Sample ID } \\
\end{array}$ & $\begin{array}{c}\text { Sample Size } \\
\text { ml or gm }\end{array}$ & $\begin{array}{l}\text { Mass Spec. } \\
\text { Sample ID }\end{array}$ & $\begin{array}{l}\text { Sample Size } \\
\text { ml or } \mathrm{gm}\end{array}$ \\
\hline GS-1 & Surface Water & $6-23-94$ & 11910 & 2000 & 11897 & 500 \\
\hline $\mathrm{MCO}-4$ & Groundwater & $6-23-94$ & 11923 & 2000 & 11915 & 500 \\
\hline $\mathrm{MCO}-5$ & Groundwater & $6-23-94$ & 11924 & 2000 & 11916 & 500 \\
\hline MCO-6 & Groundwater & $6-27-94$ & 11925 & 2000 & 11917 & 500 \\
\hline MCO-7 & Groundwater & $6-27-94$ & - & 2000 & 11931 & 500 \\
\hline MCO-7.5 & Groundwater & $6-27-94$ & 11926 & 2000 & 11918 & 500 \\
\hline $\begin{array}{c}\text { Mortandad @ } \\
\text { MCO-13 } \\
\text { (A5) }\end{array}$ & Sediment & $7-27-94$ & 12115 & 53.4 & 11953 & 2.1 \\
\hline $\begin{array}{l}\text { Laboratory } \\
\text { Boundary } \\
\text { Transect } \\
\text { (MTC) }\end{array}$ & Sediment & $7-27-94$ & 12103 & 36.1 & 11960 & 1.8 \\
\hline A7 & Sediment & $7-27-94$ & 12101 & 43.8 & 12536 & 2.1 \\
\hline A8 & Sediment & $7-27-94$ & 12174 & 46.5 & 12537 & 3.2 \\
\hline $\begin{array}{c}\text { Mortandad@ } \\
\text { SR-4 (A9) }\end{array}$ & Sediment & $6-03-94$ & 12013 & 48.1 & 11880 & 2.0 \\
\hline A10 & Sediment & $7-27-94$ & 12102 & 45.1 & 11961 & 1.3 \\
\hline $\begin{array}{c}\text { Mortandad } \\
\text { @ Rio Grande } \\
\text { (A11) }\end{array}$ & Sediment & 9-27-94 & 12668 & 38.9 & 12533 & 3.5 \\
\hline
\end{tabular}

